\title{
Use of Wood Resources in Central Argentina: A multivariate approach for the study of phytogeography and culture
}

\author{
Santiago Rodríguez López, Bárbara Arias \\ Toledo, and Leonardo Galetto
}

\section{Research}

\begin{abstract}
Changes in land use and forest loss determine not only the loss of biodiversity, but the associated traditional ecological knowledge. Thus, knowing the several uses of forest resources by rural communities might help in guiding conservation efforts. We applied a multivariate approach to evaluate knowledge on uses of wood species-based on environmental factors and participants' $(N=114)$ socioeconomic characteristics-in six rural communities of Córdoba Province, Argentina, located in three different phytogeographical areas. Older men with unstable jobs and low education represent the embodiment of those who know about wood resources. Although the multivariate analysis suggests that socioeconomic factors are important when determining the known uses of wood resources within each area, environmental factors such as the availability of species considerably contribute to the characterization of the different communities. Quantitative analysis, including the socioeconomic characterization of human populations, might provide a valuable tool when planning policies for management and conservation of fuelwood resources.
\end{abstract}

\section{Introduction}

Traditional ecological knowledge is the group of knowledge, practices, and beliefs maintained through generations by cultural transmission, which contributes to a better integration and adaptation of individuals to the environment. The use of wild plants is part of this knowledge in different human populations (Berkes 1999), and for those populations located in areas with marked seasons, those resources available along the entire year such as crust and woods become especially important (Albuquerque \& Andrade 2002, Albuquerque et al. 2005).
The use that human populations make of the environment depends on both the possibilities that it provides and the perception that individuals have of it. This perception is influenced by, among others, socioeconomic factors (Arango Caro 2004, Arias Toledo 2006), the gain or loss of traditional knowledge (Benz et al. 2000), and other characteristics from specific societies and cultures (Alexiades 1996). However, and despite its relevance, how traditional knowledge on the use of species is distributed according to informants' socioeconomic characteristics has not been well studied. Thus, e.g., in a review of previous works published from 1981-2004, Pfeiffer and Butz (2005) found that less than $5 \%$ of the papers examined gender variation in the ethnobiological knowledge and practices.

The availability of vegetal resources is determined to a great extent by the diversity of plants in a particular environment (Prance 1995). In rural communities, one of the biggest demands is the use of plant resources as fuel-

\section{Correspondence}

Santiago Rodríguez López, Bárbara Arias Toledo, Leonardo Galetto, Consejo Nacional de Investigaciones Científicas y Técnicas, Rondeau 467, 1er piso. C.P: 5000 . Córdoba, ARGENTINA. santiago.rodriguez@conicet.gov.ar Bárbara Arias Toledo, Antropología, Facultad de Ciencias Exactas, Físicas y Naturales, Universidad Nacional de Córdoba, ARGENTINA.

Leonardo Galetto, Instituto Multidisciplinario de Biología Vegetal (UNC-CONICET), Facultad de Ciencias Exactas, Físicas y Naturales, Universidad Nacional de Córdoba, ARGENTINA.

Ethnobotany Research \& Applications 14:381-392 (2015)

Published: 17 December 2015

http://dx.doi.org/10.17348/era.14.0.381-392 
wood, and this demand might vary due to the quality of wood, its availability, accessibility, social and economic factors, etc. (Ogunkunle \& Oladele 2004, Samant et al. 2000, Tabuti et al. 2003). Consequently, and given the excessive use pressure on forests, identifying the major users of forest resources can help in guiding conservation efforts (de Medeiros et al. 2012).

The Córdoba Province in Argentina has a varied geography with different ecosystems. However, the forest exploitation together with the advance of agricultural frontiers, determine not only the loss of biodiversity, but also the associated traditional knowledge on natural resources by the populations that are directly affected by these problems (Arias Toledo et al. 2010). These processes rapidly promote the discredit and disuse of several vegetal resources (Caballero 1986); thus, addressing these issues is relevant since this region is characterized not only by the availability of timber and fuelwood resources of valuable quality such as algarrobos (Prosopis sp.), quebracho blanco (Aspidosperma quebracho-blanco Schltdl.), and espinillo (Acacia caven var. caven (Molina) Molina), but also by other important medicinal and edible resources.

Studies on the use of forest resources and conservation have been previously conducted in semi-arid regions (de Medeiros et al. 2011, 2012, Ramos et al. 2012, 2014). Due to the persistent decline experienced by these regionsincluding the native forest areas of Córdoba (Zak et al. 2004) - it is relevant to study the knowledge and uses of wood resources, considered as critical in low-income rural populations (Binford 1980), and their associated factors. Thus, the present study is focused on assessing the availability, knowledge, and uses of wood resources by rural communities located in different phytogeographical areas in Córdoba Province, Argentina, in relation to informants' socioeconomic characteristics.

\section{Materials and Methods}

\section{Study areas}

The studied communities are located within the chaco phytogeographical region (Cabrera 1976), formed by different phytogeographical areas with a great floristic diversity. The studied communities are grouped in three different areas within this region (Figure 1):

\section{Chaco serrano (hilly chaco)}

The area of chaco serrano extends throughout the following systems: Sierras chicas, Sierras grandes, and Sierras de Pocho-Guasapampa, at altitudes ranging from 400 to $1300 \mathrm{~m}$ (Cabrera 1976). There is a marked rain seasonality, mostly in spring and summer, with a yearly average around $800 \mathrm{~mm}$ (Torres \& Galetto 2011). In this location we studied the rural communities of Villa Los Aromos (VLA) and La Paisanita (LP). They are both characterized by forest and scrubs distributed in the lowest part of the hills.

\section{$\underline{\text { Chaco árido (arid chaco) }}$}

The driest part of the chaco, known as chaco árido, is located to the west of Córdoba. The diverse and unpredictable climate, together with a great daily temperature variation, is very common in this area. The arboreal stratum is limited, and the shrub is continuous (known as xerophile low forest or scrub), with annual average rainfall around $500 \mathrm{~mm}$ (Cabido et al. 1991). In this area we studied the rural locations of San Vicente and San Martín. Most of the chaco árido has suffered from timber extraction and overgrazing while the remaining is almost exclusively a secondary forest formed by dense shrubs and a few trees (Cabido \& Zak 1999). Thus, the main production systems are extensive livestock and forest exploitation limited to the production of fuelwood and charcoal (Karlin et al. 1992).

\section{Chaco seco (dry chaco)}

To the north of the chaco region the hills are lower, but the vegetation is distributed in altitudinal levels with forest between 700 and $1200 \mathrm{~m}$, shrubbery between 900 and $1500 \mathrm{~m}$, and grassland from $1500 \mathrm{~m}$ on. The weather gets warmer and drier when moving from east to west, while temperatures become lower, and there is more water availability when going up the hills due to increased local rainfall and a lower evapotranspiration rate (Cabido \& Zak 1999). Within this area we considered the communities of Rayo Cortado and Chañar Viejo, where human activities including logging, intentional fires, and overgrazing have dramatically modified the area's physiognomy.

\section{Working methods}

\section{Sampling and variables}

In order to estimate the knowledge and uses of wood resources by the informants, we performed one interview per household. Interviews were semi-structured (Bernard 1994) or semi-standardized (Padua \& Ahman 1994) and included ethnographical methods used in ethnobotany (Capparelli \& Raffino 1997). These were combined with analytical techniques for social sciences (Padua \& Ahman 1994). Interviews covered (i) basic demographic characteristics (sex, age, and marital status); (ii) data on the number and type of wood resources known and used by the informants; (iii) economic characteristics (type of job, make ends meet, etc.); (iv) geographic characteristics (distance to the site where wood is collected, distance covered for daily activities, etc.); and (v) educational access (maximum educational level achieved). Interviews 


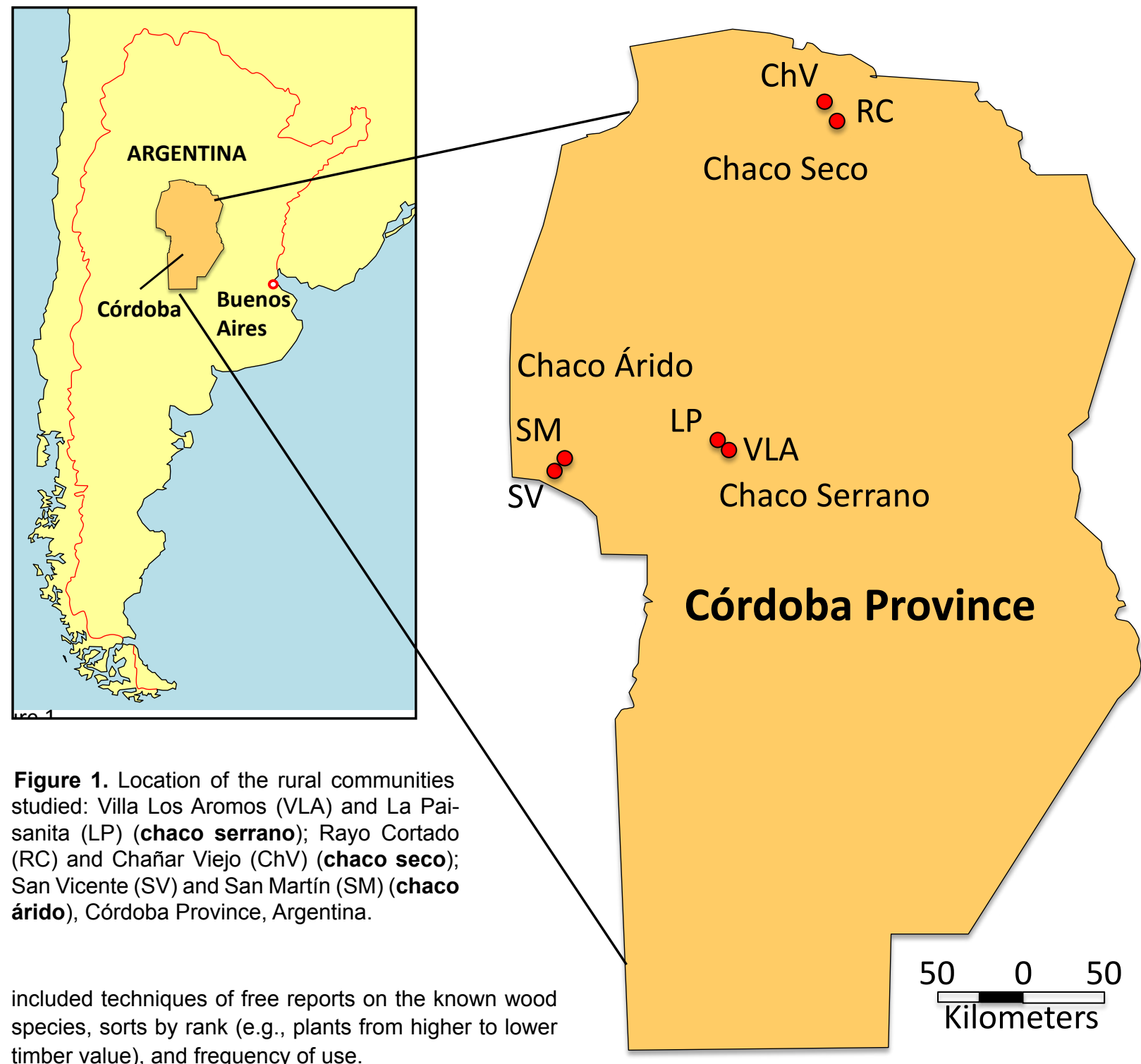

Additionally, timber counts were carried out in order to assess species availability in every community. We selected specific areas based on our observations, recollection areas, and joint walks with the informants. In every community, we considered a total of five 100-m transects (and areas of $25 \mathrm{~m}^{2}$ when possible). Although it is likely that some species can eventually be located in isolated areas, these timber counts largely include most of the reported wood specimens.

\section{$\underline{\text { Statistical analysis }}$}

First, we performed a principal component analysis (PCA) to observe spatial associations among variables, including self-reports of known species, specimens sur- veyed in timber counts, and sociocultural variables within each community.

Then, we calculated the frequency of the distribution of known wood resources for each community and for the total area. We evaluated the association between such knowledge with socioeconomic factors and indicators of geographic access (sex, age, origin, educational level, type of job, way of access to the resources, and the use of alternative resources) by means of non-parametric ANOVA (including Kruskal-Wallis and Dunn's post-hoc tests). Informants' origin was defined as "native" when, even coming from urban areas, informants had lived in the communities for at least 15 years; and otherwise as "immigrants." 


\section{Plant collection}

Both the species mentioned as used by the informants and those surveyed in timber counts were collected, identified, and made into herbarium voucher specimens. Specimens collected and identified with informants were deposited at the CORD herbarium (Botany Museum, Universidad Nacional de Córdoba, Argentina) with voucher specimens under the signature of Bárbara Arias Toledo (see Supplementary Material for identification numbers). The scientific names were assigned and corroborated first using Flora Argentina (2014) and then The Plant List (2015).

\section{Results}

Interviews covered a total of 114 individuals (81 women and 33 men) aged 14-84 years. A list of 47 known and used wood species, including 35 native and 12 exotic taxa (with their respective scientific and vernacular names and the main uses reported by the interviewed participants), is reported in Appendix 1.

Figure 2 shows the relationship pattern among the known and used resources, the different phytogeographical areas (as an environmental variable), and socioeconomic factors. The first two components (PC1 and PC2) explain almost $84 \%$ of the variability. Graphically, the six communities are grouped according to the three areas of the chaco considered. PC1 has a positive correlation with some species mentioned in the chaco serrano, such as the native espinillo and moradillo, or the exotic ones such as eucalipto and acacia negra. Similarly, there is a positive correlation for more species available in this area, such as paraíso (exotic), espinillo, moradillo, molle, and other native species.

On the other hand, PC1 has a negative correlation with those species reported in the area of the chaco árido such as algarrobo, brea, jarilla, atamisqui, and retamo (all native species), and with those actually available in timber counts such as duraznillo, peje, tuna, retamo, brea, algarrobo, and others. This negative correlation with PC1 is also observed with other socioeconomic variables such as the knowledge of species by men, by adult individuals, and by those who buy wood, which are grouped in the area of chaco árido. The correlation among these variables isolates the communities of chaco serrano from those of chaco árido. PC2 has a positive correlation with a great number of variables, characterizing the communities in the chaco seco and isolating them from the other ones. Some examples are the species reported by the informants in those communities (RC and $\mathrm{ChV}$ ), such as the native ones tintitaco, garabato, itín, quebracho blanco, and mistol. Other variables are represented by their presence in timber counts, such as tala, algarrobo, cardón, tusca, siempre verde, quebracho blanco, mistol, and others.
The known wood resources sorted by the informants' socioeconomic characteristics are shown in Table 1. There are non-significant differences in the median number of known species among the communities. Compared to women or younger informants, men and older participants reported higher knowledge of wood resources. Those informants with none or unstable jobs, and those

Table 1. Knowledge distribution of wood resources by informants' socioeconomic characteristics. $N$ : number of informants; Median: median number of species cited within each group. The remaining variables refer to participants. Non-parametric ANOVAs (Kruskal-Wallis) were performed; aindicates differences between categories, estimated by Dunn's post-hoc test; bindicates the use of alternative resources, mainly liquid gas bottles.

\begin{tabular}{|c|c|c|c|c|}
\hline \multicolumn{2}{|c|}{ Variables } & $N$ & Median & $p$ \\
\hline \multicolumn{5}{|c|}{ Communities } \\
\hline & Villa Los Aromos & 22 & $5.0 \pm 4.1$ & \multirow[t]{6}{*}{0.245} \\
\hline & La Paisanita & 12 & $7.0 \pm 1.7$ & \\
\hline & Rayo Cortado & 25 & $5.0 \pm 2.9$ & \\
\hline & Chañar Viejo & 14 & $6.0 \pm 2.8$ & \\
\hline & San Vicente & 28 & $4.5 \pm 2.4$ & \\
\hline & San Martín & 13 & $5.5 \pm 2.7$ & \\
\hline \multicolumn{5}{|l|}{ Sex } \\
\hline & Men & 33 & $7.0 \pm 2.7$ & \multirow[t]{2}{*}{$<0.001$} \\
\hline & Women & 81 & $5.0 \pm 2.8$ & \\
\hline \multicolumn{5}{|c|}{ Age (years) } \\
\hline & 15-45 years & 69 & $5.0 \pm 2.8$ & \multirow[t]{2}{*}{$<0.05$} \\
\hline & 46 and more & 45 & $7.0 \pm 3.1$ & \\
\hline \multicolumn{5}{|c|}{ Origin } \\
\hline & Native & 83 & $5.0 \pm 2.8$ & \multirow[t]{2}{*}{0.800} \\
\hline & Immigrant & 31 & $5.0 \pm 3.4$ & \\
\hline \multicolumn{5}{|l|}{ Job } \\
\hline & Stable & 35 & $4.0 \pm 3.3$ & \multirow[t]{2}{*}{$<0.05$} \\
\hline & Unstable/no job & 79 & $6.0 \pm 2.8$ & \\
\hline \multicolumn{5}{|c|}{ Educational level } \\
\hline & Primary & 76 & $6.0^{\mathrm{a}} \pm 2.8$ & \multirow[t]{3}{*}{$<0.05$} \\
\hline & High school & 31 & $4.0^{\mathrm{a}} \pm 2.8$ & \\
\hline & High/University & 7 & $5.0 \pm 4.5$ & \\
\hline \multicolumn{5}{|c|}{ Access to resources } \\
\hline & Collect & 77 & $7.0 \pm 2.7$ & \multirow[t]{2}{*}{$<0.001$} \\
\hline & Buy/Given & 24 & $4.0 \pm 2.1$ & \\
\hline \multicolumn{5}{|c|}{ Alternative resource $^{b}$} \\
\hline & Yes & 97 & $5.0 \pm 2.8$ & \multirow[t]{2}{*}{0.071} \\
\hline & No & 17 & $4.0 \pm 3.4$ & \\
\hline
\end{tabular}




\section{Rodríguez López et al. - Use of Wood Resources in Central Argentina: A multivariate approach for the study of phytogeography and culture}

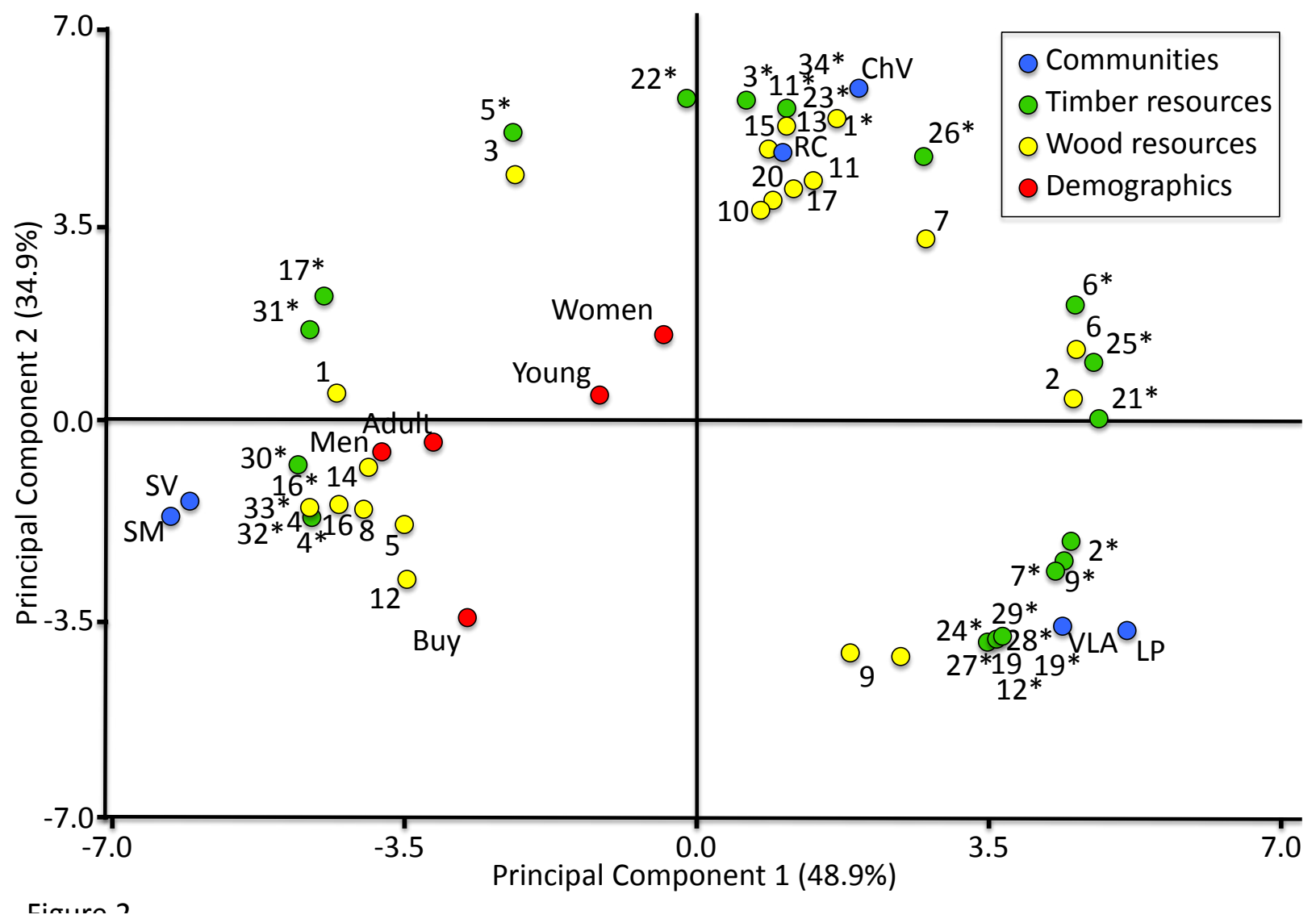

Figure 2. Principal component analysis including: self-reports of known wood resources (yellow dots), counted timber resources (green dots), and sociodemographic characteristics (red dots). Communities (blue dots): Villa Los Aromos (VLA), La Paisanita (LP), Rayo Cortado (RC), Chañar Viejo (ChV), San Martín (SM), and San Vicente (SV). Wood resources: Prosopis alba var. alba Griseb. algarrobo (1), Acacia caven var. caven (Molina) Molina espinillo (2), Aspidosperma quebracho-blanco Schltdl. quebracho blanco (3), Parkinsonia praecox (Ruiz \& Pav.) Hawkins brea (4), Acacia aroma Hook. \& Arn. tusca (5), Schinus fasciculata (Griseb.) I.M.Johnst. moradillo (6), Condalia microphylla Cav. piquillín (7), Larrea divaricata Cav. jarilla (8), Melia azedarach L. paraíso (9), Prosopis torquata (Lag.) DC. tintitaco (10), Ziziphus mistol Griseb. mistol (11), Populus alba L. álamo (12), Acacia praecox Griseb. garabato (13), Atamisquea emarginata Miers ex Hook. \& Arn. atamisqui (14), Prosopis kuntzei Kuntze itín (15), Bulnesia retamo (Gillies ex Hook. \& Arn.) Griseb. retamo (16), Jodina rhombifolia (Hook. \& Arn.) Reissek peje (17), Salix humboldtiana var. humboldtiana Willd. sauce (18), Cecropia pachystachya Trécul cafeto (19), Porlieria microphylla (Baill.) Descole, O'Donell \& Lourteig pan de cata (20), Bouganvillea stipitata Griseb. tala falso (21), Celtis iguanaea (Jacq.) Sarg. tala (22), Stetsonia coryne (Salm-Dyck) Britton \& Rose cardón moro (23), Zanthoxylum coco Gillies ex Hook. f. \& Arn. coco (24), Lithraea molleoides (Vell.) Engl. molle (25), Ligustrum lucidum W.T.Aiton siempre verde (26), Gleditsia triacanthos L. acacia negra (27), Geoffroea decorticans (Hook. \& Arn.) Burkart chañar (28), Platanus acerifolia (Aiton) Willd. plátano (29), Opuntia ficus-indica (L.) Mill.var. ficus indica tuna (30), Cestrum parqui (Lam.) L'Hér. duraznillo (31), Prosopis nigra Hieron. algarrobo negro (32), Prosopis sp. algarrobo dulce (33), and Schinus areira L. aguaribay (34).

with low educational background (primary school; $66 \%$ of participants) also reported greater use of species than those with stable jobs and those with high-school education. Moreover, informants who collect wood have greater knowledge than those who buy it or receive it (as favors by a community's authorities or as payments).

\section{Discussion}

Our study showed the importance of considering socioeconomic factors, in addition to the availability and diversity of resources, when studying the knowledge and use of wood resources in rural communities. 
Gender is an important aspect when evaluating these results, due to its relationship with other socioeconomic factors such as occupation, educational attainment, social status, access to resources, etc. (di Leonardo 1991, Sarin 1998). We found that men reported greater knowledge of wood resources than women. This finding is in line with previous studies reporting that compared to women, men have a deeper knowledge than women about uses of timber resources, mainly trees (Hanazaki et al. 2000), while women seem to have a wider knowledge of non-forest species, mostly medicinal herbs (Arias Toledo 2006, Arias Toledo et al. 2007, Phillips \& Gentry 1993). In our study, men are generally in charge of providing fuelwood for their homes. Performing these activities in the forest allows them direct contact with the resources and contributes to maintenance of these facts. In this sense, most authors agree that gender differences in the use of plants are linked to the cultural role of every group in the communities (Cotton 1996, Kainer \& Duryea 1992).

Age is also an important factor in the knowledge of wood resources (Arango Caro 2004, Figueiredo et al. 1993, Hanazaki et al. 2000, Rossato et al. 1999), with greater knowledge among older individuals. Similar results were described by Phillips and Gentry (1993) among participants of southeast Peru, in which the knowledge of plants used for construction is higher among individuals around 30-50 years old. We observed differences regarding gender and age in the chaco árido, in which the difference between men and women in relation to daily activities is marked. Men work in the fields along the year, and women work in the fields mainly during potato harvest season, taking care of household labor during the rest of the year. The main economic activities are potato plantations, together with work in brick and charcoal ovens where men are engaged in their daily activities. These give them a more direct contact with fuelwood resources, contributing to their higher knowledge of fuelwood.

Surprisingly, access to fuelwood resources and the job situation of informants are not related (non-significant correlation). This might be due to the high number of informants ( $83 \%$ of the total) who use some kind of alternative resource to wood, mainly liquid gas bottles. The use of liquid gas in these communities is a common complement to the use of fuelwood, somehow independent of the household income. Moreover, we found no differences either in the use of these alternative resources among the communities or in the informants' origin.

The absence of a stable job is associated with a low level of education in our study. We found that educational attainment is an important factor associated with knowledge of wood resources, being higher among those individuals with primary studies, followed by those with the highest education. Similar results for other types of vegetal species (edible and medicinal) were previously reported in the same study areas (Arias Toledo 2006), suggesting that informants with university studies are mainly immigrants from urban areas who have decided to live in rural environments and have a specific interest in nature. This is clearer in the area of chaco serrano due to its location, relatively close to urban areas. Overall, we highlight that older men with unstable jobs and lower education embody the profile of the knower of wood resources. Previous studies showed that the characterization of the major users of forest may be valuable when promoting conservation efforts (de Medeiros et al. 2012), and our findings support this notion, especially for older men with unstable jobs and low educational backgrounds.

In addition to bivariate analysis, multivariate analysis of environmental factors and informants' socioeconomic characteristics allowed us to characterize the studied communities and the areas where they are located. The associations show the differentiation of the communities in the chaco árido from the other ones. This might be due (in addition to regional differences in floristic composition and land uses) to a higher preference of the interviewees (mainly older adults) for some particular species that are common in the chaco árido such as brea, retamo, atamisqui, tala, and jarilla, all widely used in this area for charcoal and brick ovens. Moreover, knowledge per capita is the lowest in this area, which might suggest that this knowledge is focused on some specific resources, as described above.

The chaco serrano is mainly characterized based on selfreported species (also available in abundance) such as espinillo, moradillo, paraíso, and acacia negra. Some of these are widely-used invasive exotics typical from these communities, whose appearance is a consequence of sustained logging in the area. The effect of these variables separates the chaco serrano from the chaco árido. Furthermore, these areas are also grouped according to the described socioeconomic variables which are not shared by the communities in the chaco seco where middle-education informants and those who buy wood are knowledgable young men.

The described pattern of relationships in multivariate analysis groups those informants who buy wood near the communities of the driest part of the chaco, where the availability of wood resources is lower. Wood is a limited resource in most of these areas and at the same time, a widely used resource in rural communities. The scarcity of wood resources and the increasing needs of rural populations lead to non-selective use and favoring quantity instead of quality. Thus, the use of fuelwood seems to be relatively independent from the quality and the intrinsic properties of the species. Surprisingly, educational attainment and employment situation are not relevant in multivariate analysis. Although social and cultural factors are relevant when defining the composition of known wood species, environmental factors also play an important (and perhaps more relevant) role. Conversely, other mul- 


\section{Rodríguez López et al. - Use of Wood Resources in Central Argentina: A multivariate approach for the study of phytogeography and culture}

tivariate studies in these areas considering the uses and knowledge of edible and medicinal plants showed that socioeconomic factors were more important in the composition of known species (Arias Toledo et al. 2009). Such differences might suggest that the use of different vegetal resources might be defined by specific selection criteria that are non-extrapolated, or by the availability of species in the different chaco regions.

The current situation of all the studied areas (bosque chaqueño) greatly differs from what was described in the beginning of the $20^{\text {th }}$ century about the abundance, diversity, and use of resources (Río \& Achával 1905). It is clear that the native populations had to adapt to the changes suffered by the environment since then. Within this context-and despite considering the steady reduction of species abundance and the consequent loss of the associated traditional knowledge-it is interesting to know how this adaptation would have arisen through understanding the changes that have occurred in the ecological perception of individuals (Rocha 2004). The use of quantitative analysis of socioeconomic effects on different communities is necessary to achieve this goal. This allows for the comparison of human populations from different environments and for acting accordingly. This method could be a first step when devising management and conservation policies of natural resources with human populations (Hanazaki et al. 2000), especially when the main conservation efforts are focused on fuelwood resources (de Medeiros et al. 2011).

In conclusion, our results show the importance of considering socioeconomic factors in addition to species availability when studying the composition of wood species known in rural communities and their potential use as management and conservation tools directed to each particular area. This study provides an approach to the interpretation of the complexity related to the construction of the traditional ecological knowledge in rural communities.

\section{Acknowledgments}

The authors are grateful to all the informants who generously agreed to participate in this study. LG thanks "Secretaría de Ciencia y Técnica" (Universidad Nacional de Córdoba) and "Consejo Nacional de Investigaciones Científicas y Técnicas" (CONICET) for providing financial support. SRL, BAT, and LG are researchers at CONICET.

\section{Literature Cited}

Albuquerque, U.P. \& L.H. Andrade. 2002. Conhecimento botânico tradicional e conservação em uma área de caatinga no Estado de Pernambuco, Nordeste do Brasil. Acta Botanica Brasilica 16:273-285. dx.doi.org/10.1590/ $\underline{\text { S0102-33062002000300004 }}$
Albuquerque, U.P., A.C.O. Silva \& L.H. Andrade. 2005. Use of plant resources in a seasonal dry forest (northeastern Brazil). Acta Botanica Brasilica 19:27-38. dx.doi. org/10.1590/S0102-33062005000100004

Alexiades, M. 1996. Selected Guidelines for Ethnobotanical Research: A field manual. The New York Botanical Garden, New York, New York, U.S.A.

Arango Caro, S. 2004. Ethnobotanical studies in the Central Andes (Colombia): Knowledge distribution of plant use according to informant's characteristics. Lyonia 7(2):89104.

Arias Toledo, B. 2006. Aspectos cuantitativos, cualitativos y simbólicos de la medicina tradicional de los pobladores criollos de Cerro Colorado (Córdoba, Argentina). Revista Pinaco - Investigaciones sobre Antropología Cognitiva 5:105-115.

Arias Toledo, B., S. Colantonio \& L. Galetto. 2007. Knowledge and use of food and medicinal plants in two populations from the Chaco, Córdoba province, Argentina. Journal of Ethnobiology 27(2):218-232. dx.doi. org/10.2993/0278-0771(2007)27[218:KAUOEA]2.0.CO;2

Arias Toledo, B., L. Galetto \& S. Colantonio. 2009 Ethnobotanical knowledge in rural communities of Córdoba (Argentina): The significance of cultural and biogeographical factors. Journal of Ethnobiology and Ethnomedicine 5:40-48. dx.doi.org/10.1186/1746-4269-5-40

Arias Toledo, B., C. Trillo \& M. Grilli. 2010. Uso de plantas medicinales en relación al estado de conservación del bosque en Córdoba, Argentina. Ecología Austral 20:235246.

Benz, B.F., F. Santana, J. Rosales \& S. Graf. 2000. Losing knowledge about plant use in the Sierra de Manatlan Biosphere Reserve, México. Economic Botany 54(2):183191. dx.doi.org/10.1007/BF02907821

Bernard, H. 1994. Research Methods in Anthropology Second edition. Altamira Press, Walnut Creek, California, U.S.A.

Berkes, F. 1999. Sacred Ecology: Traditional ecological knowledge and resource management. Taylor \& Francis, Philadelphia, Pennsylvania, U.S.A.

Binford, L. 1980. Willow smoke and dogs' tails: Hunter-gatherer settlement systems and archaeological site formation. American Antiquity 45:4-20. dx.doi. org/10.2307/279653

Caballero, J. 1986. Etnobotánica y desarrollo. La búsqueda de nuevos recursos vegetales. Pp. 79-96 in Memorias IV Congreso Latinoamericano de Botánica. Simposio Et- 
nobotánica. Instituto Colombiano para el Fomento de la Educación Superior, Bogotá, Colombia.

Cabrera, A. 1976. Regiones fitogeográficas Argentinas. Enciclopedia Argentina Agricultura y Jardinería. ACME, Buenos Aires, Argentina.

Capparelli, A. \& R. Raffino. 1997. La etnobotánica de "El Shincal" (Catamarca) y su importancia para la arqueología: Recursos combustibles y madereros. Parodiana 10(1-2):165-180.

Cotton, C.M. 1996. Ethnobotany. Principles and applications. John Wiley \& Sons. Chichester, UK.

di Leonardo, M. 1991. Introduction. Pp. 1-48 in Gender at the Crossroads of Knowledge: Feminist anthropology in historical perspective. Edited by M. di Leonardo. University of California Press, Berkeley, California, U.S.A. dx.doi. org/10.1007/978-1-349-21445-7 1

de Medeiros, P.F., L. Santos de Almeida, T.C. da Silva \& U.P. Albuquerque. 2011. Pressure indicators of wood resource use in an Atlantic Forest Area, Northeastern Brazil. Environmental Management 47:410-424. dx.doi. org/10.1007/s00267-011-9618-3

de Medeiros, P.F., T.C da Silva, L. Santos de Almeida \& U.P. Albuquerque. 2012. Socio-economic predictors of domestic wood use in an Atlantic forest area (north-east Brazil): A tool for directing conservation efforts. International Journal of Sustainable Development \& World Ecology 19(2):189-195. dx.doi.org/10.1080/13504509.2011.6 14288

Figueiredo, G.M., H. Leitao-Filho \& A. Begossi. 1993. Ethnobotany of Atlantic forest coastal communities: Diversity of plant uses in Gamboa (Itacuruçá Island, Brazil). Human Ecology 21:419-430. dx.doi.org/10.1007/BF00891142

Flora Argentina. 2014. Flora Argentina: Plantas vasculares de la Republica Argentina. www.floraargentina.edu.ar Accessed 30 April 2014.

Hanazaki, N., J. Tamashiro, F. Hermògenes \& A. Begossi. 2000. Diversity of plant uses in two Caiçara communities from Atlantic Forest coast, Brazil. Biodiversity and Conservation 9:597-615. dx.doi.org/10.1023/A:1008920301824

Kainer, K.A. \& M.L. Duryea. 1992. Tapping women's knowledge: Plant resource use in extractive Reserves, Acre, Brazil. Economic Botany 46:408-425. dx.doi. org/10.1007/BF02866513

Karlin, U., R. Coirini, L. Pietrarelli \& E. Perpiñal. 1992. Caracterización del Chaco Árido y propuesta de recuperación del recurso forestal. Pp. 7-12 in Sistemas Agro- forestales para pequeños productores de Zonas Áridas. Proyecto de Desarrollo Agroforestal en Comunidades Rurales del Noroeste Argentino. Edited by U. Karlin \& R. Coirini. Sociedad Alemana de Cooperación Técnica. Córdoba, Argentina.

Ogunkunle, A.T.J. \& F.A. Oladele. 2004. Ethnobotanical study of fuelwood and timber wood consumption and replenishment in Ogbomoso, Oyo State, Nigeria. Enviromental Monitoring and Assessment 91:223-236. dx.doi. org/10.1023/B:EMAS.0000009238.10891.c0

Padua, J. \& I. Ahman. 1994. La organización de un "survey." Pp. 11-27 in Técnicas de Investigación Aplicadas a las Ciencias Sociales. Edited by J. Padua, I. Ahman, H. Apezechea \& C. Borsotti. Sección de Obras de Sociología, Fondo de Cultura Económica, Santiago, Chile.

Pfeiffer, J.M. \& R.J. Butz. 2005. Assessing cultural and ecological variation in ethnobiological research: The importance of gender. Journal of Ethnobiology 25(2):240278. dx.doi.org/10.2993/0278-0771(2005)25[240:ACAEV 1]2.0.CO:2

Phillips, O. \& A.H. Gentry. 1993. The useful plants of Tamboapta, Perú: I. Statistical hypothesis testing with a new quantitative technique. Economic Botany 47:15-32. dx.doi.org/10.1007/BF02862203

Prance, G.T. 1995. A comparison of the efficacy of higher taxa and species numbers in the assessment of the biodiversity in the neotropics. Pp. 89-99 in Biodiversity. Measurement and estimation. Edited by D.L. Hawksworth. Chapman \& Hall, London, U.K.

Ramos, M.A., \& U.P. Albuquerque. 2012. The domestic use of firewood in rural communities of the Caatinga: How seasonality interferes with patterns of firewood collection. Biomass and Bioenergy 39:147-158. dx.doi. org/10.1016/j.biombioe.2012.01.003

Ramos, M.A., P.M. de Medeiros \& U.P. Albuquerque. 2014. Methods and techniques applied to ethnobotanical studies of timber resources. Pp. 349-365 in Methods and Techniques in Ethnobiology and Ethnoecology. Edited by U.P. Albuquerque, L.V.F. Cruz da Cunha, R.F.P. Lucena \& R.R.N. Alves. Springer, New York, New York, U.S.A. dx.doi.org/10.1007/978-1-4614-8636-7 22

Río, M.E. \& L. Achával. 1905. Geografía de la Provincia de Córdoba. Volume 2. Publicación oficial. Buenos Aires, Argentina.

Rocha, J. 2004. Cambios en la percepción de los recursos naturales como resultado de la participación en la economía de mercado. Una comunidad campesina de los Andes peruanos. Anthropologica 22(22):179-213. 


\section{Rodríguez López et al. - Use of Wood Resources in Central Argentina: A multivariate approach for the study of phytogeography and culture}

Rossato, S., H. Leitão-Filho \& A. Begossi. 1999. Ethnobotany of Caiçaras of the Atlantic Forest coast (Brazil). Economic Botany 53(3):377-385. dx.doi.org/10.1007/ bf02866716

Samant, S.S., U. Dhar \& R.S. Rawal. 2000. Assessment of fuel resource diversity and utilization patterns in Askot Wildlife Santuary in Kumaum Himalaya, India, for conservation and management. Environmental Conservation 27(1):5-13. dx.doi.org/10.1017/S0376892900000023

Sarin, M. 1998. Who is Gaining? Who is Losing? Gender and equity concerns in joint forest management. Society for Promotion of Wastelands Development, New Delhi, India.

Tabuti, J.R.S., S.S. Dhillon \& K.A. Lye. 2003. Firewood use in Bulamogi Country, Uganda: Species selection, harvest- ing and consumption patterns. Biomass and Bioenergy 25:581-596. dx.doi.org/10.1016/S0961-9534(03)00052-7

The Plant List. 2015. The Plant List. www.theplantlist.org Accessed 30 November 2015.

Torres, C. \& L. Galetto. 2011. Flowering phenology of cooccurring Asteraceae: Matter of climate, ecological interactions, plant attributes, or evolutionary relationships among species? Organisms Diversity \& Evolution 11:919. dx.doi.org/10.1007/s13127-011-0038-2

Zak, M.R., M. Cabido \& J.G. Hodgson. 2004. Do subtropical seasonal forest in the Gran Chaco, Argentina, have a future? Biological Conservation 120:589-598. dx.doi. org/10.1016/j.biocon.2004.03.034 
Appendix 1. Self-reports and availability of wood resources in the six studied communities (Villa Los Aromos, La Paisanita, Rayo Cortado, Chañar Viejo, San Martín, and San Vicente) in three distinct parts of the chaco phytogeographical area (chaco serrano, chaco seco, and chaco árido) in Córdoba province, Argentina. Wood resources are represented in the communities where they were registered at least on one occasion. $\dagger=$ exotic species; vouchers specimens are deposited in the CORD herbarium at the Botany Museum, Universidad Nacional de Córdoba, Argentina.

\begin{tabular}{|c|c|c|c|c|c|c|c|c|}
\hline \multirow[t]{2}{*}{ Plant names } & \multicolumn{6}{|c|}{$\begin{array}{c}\text { Communities in } \\
\text { phytogeographical areas of chaco }\end{array}$} & \multirow[t]{4}{*}{ Main uses } & \multirow{4}{*}{ 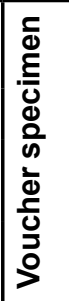 } \\
\hline & \multicolumn{2}{|c|}{ serrano } & \multicolumn{2}{|c|}{ seco } & \multicolumn{2}{|c|}{ árido } & & \\
\hline Scientific & 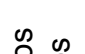 & & & & & & & \\
\hline Vernacular & 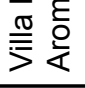 & 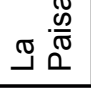 & 啇 & 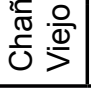 & 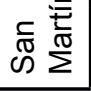 & 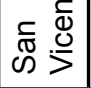 & & \\
\hline \multicolumn{7}{|c|}{ Acacia aroma Hook. \& Arn. } & & 001 \\
\hline tusca & $x$ & $x$ & $x$ & & $x$ & $x$ & & \\
\hline \multicolumn{7}{|c|}{ Acacia caven var. caven (Molina) Molina } & \multirow[t]{2}{*}{ Fences; fuelwood; fruit as fire ignition } & \multirow[t]{2}{*}{002} \\
\hline espinillo & $\mathrm{x}$ & $\mathrm{x}$ & $\mathrm{x}$ & $x$ & $x$ & $x$ & & \\
\hline \multicolumn{7}{|l|}{ Acacia praecox Griseb. } & \multirow[t]{2}{*}{ Fuelwood } & \multirow[t]{2}{*}{003} \\
\hline garabato & & & $x$ & $x$ & & & & \\
\hline \multicolumn{7}{|c|}{ Aspidosperma quebracho-blanco Schltdl. } & \multirow[t]{2}{*}{ Fuelwood } & \multirow[t]{2}{*}{004} \\
\hline quebracho blanco & $\mathrm{x}$ & $\mathrm{x}$ & $\mathrm{x}$ & $x$ & $x$ & $x$ & & \\
\hline \multicolumn{7}{|c|}{ Atamisquea emarginata Miers ex Hook. \& Arn. } & \multirow[t]{2}{*}{ Unpleasant odor so not used as fuelwood } & \multirow[t]{2}{*}{007} \\
\hline atamisqui & & & $\mathrm{x}$ & & $x$ & $x$ & & \\
\hline \multicolumn{7}{|c|}{ Bougainvillea stipitata Griseb. } & & \multirow[t]{2}{*}{005} \\
\hline talafalso & & $x$ & & & & & & \\
\hline \multicolumn{7}{|c|}{ Bulnesia retamo (Gillies ex Hook. \& Arn.) Griseb. } & \multirow[t]{2}{*}{ Stakes; fences, long-lasting wood } & \multirow[t]{2}{*}{006} \\
\hline retamo & & & & & $x$ & $x$ & & \\
\hline \multicolumn{7}{|c|}{ Casuarina cunninghamiana Miq. } & & 008 \\
\hline casuarina $^{\dagger}$ & $\mathrm{x}$ & & & & & & & \\
\hline Cecropia pachystachya & récul & & & & & & & 009 \\
\hline cafeto $^{\dagger}$ & $\mathrm{x}$ & $x$ & & & & & & \\
\hline Ceiba sp. & & & & & & & & 010 \\
\hline palo borracho & & $x$ & & & & & & \\
\hline Celtis iguanaea (Jacq.) & $\arg$ & & & & & & Fuelwood & 011 \\
\hline tala & $x$ & $x$ & $x$ & $x$ & $x$ & $x$ & & \\
\hline Cestrum parqui (Lam.) & Hér. & & & & & & & 013 \\
\hline duraznillo & & $x$ & $x$ & $x$ & $x$ & $x$ & & \\
\hline Condalia microphylla C & & & & & & & & 014 \\
\hline piquillín & $x$ & $x$ & $x$ & $x$ & & & & \\
\hline Cupressus sp. & & & & & & & & 015 \\
\hline ciprés $^{\dagger}$ & $x$ & & & & & & & \\
\hline Eucaliptus sp. & & & & & & & Fuelwood -unappreciated by its low quali- & 016 \\
\hline eucalipto $^{\dagger}$ & $x$ & $x$ & $x$ & & & & ty but abundant. Bark used for fire ignition & \\
\hline Flourensia campestris & iseb. & & & & & & & 018 \\
\hline chilca & & $x$ & & & & & & \\
\hline
\end{tabular}




\section{Rodríguez López et al. - Use of Wood Resources in Central Argentina: A multivariate approach for the study of phytogeography and culture}

\begin{tabular}{|c|c|c|c|c|c|c|c|c|}
\hline \multirow{3}{*}{$\begin{array}{l}\text { Plant names } \\
\text { Scientific }\end{array}$} & \multicolumn{6}{|c|}{$\begin{array}{c}\text { Communities in } \\
\text { phytogeographical areas of chaco }\end{array}$} & \multirow[t]{4}{*}{ Main uses } & \multirow{4}{*}{ 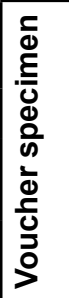 } \\
\hline & \multicolumn{2}{|c|}{ serrano } & \multicolumn{2}{|c|}{ seco } & \multicolumn{2}{|c|}{ árido } & & \\
\hline & & $\stackrel{\pi}{=}$ & & & & & & \\
\hline Vernacular & 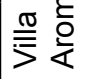 & $\widetilde{\Xi}$ & 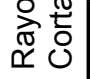 & 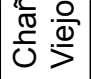 & 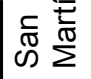 & 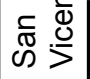 & & \\
\hline \multicolumn{7}{|c|}{ Geoffraea decorticans (Gillies ex Hook. \& Arn.) Burkart } & \multirow[t]{2}{*}{ Brak used as fire ignition } & \multirow[t]{2}{*}{019} \\
\hline chañar & $x$ & $\mathrm{x}$ & $x$ & $x$ & $\mathrm{x}$ & $x$ & & \\
\hline \multicolumn{7}{|c|}{ Gleditsia triacanthos L. } & \multirow[t]{2}{*}{ Fences; fruit used as fire ignition } & \multirow[t]{2}{*}{020} \\
\hline acacia negra $^{\dagger}$ & $\mathrm{x}$ & $x$ & & & & & & \\
\hline \multicolumn{7}{|c|}{ Heterothalamus alienus (Spreng.) Kuntze } & & \multirow[t]{2}{*}{021} \\
\hline romerillo & & $\mathrm{x}$ & & & & & & \\
\hline \multicolumn{7}{|c|}{ Jodina rhombifolia (Hook. \& Arn.) Reissek } & & \multirow[t]{2}{*}{022} \\
\hline peje & $\mathrm{x}$ & & $\mathrm{x}$ & $x$ & & & & \\
\hline \multicolumn{7}{|c|}{ Larrea divaricata Cav. } & \multirow{2}{*}{$\begin{array}{l}\text { Wood used for bread-ovens and for } \\
\text { boiling water }\end{array}$} & \multirow[t]{2}{*}{023} \\
\hline jarilla & $x$ & & & & $x$ & $x$ & & \\
\hline \multicolumn{7}{|c|}{ Ligustrum lucidum W.T.Aiton } & & \multirow[t]{2}{*}{024} \\
\hline siempre verde $^{\dagger}$ & $x$ & & & $x$ & & & & \\
\hline \multicolumn{7}{|c|}{ Lithraea molleoides (Vell.) Engl. } & \multirow{2}{*}{$\begin{array}{l}\text { Fuelwood, although fires, unpleasant } \\
\text { odor }\end{array}$} & \multirow[t]{2}{*}{025} \\
\hline molle & $x$ & $x$ & $x$ & $x$ & $x$ & $x$ & & \\
\hline Melia azedarach L. & & & & & & & & 026 \\
\hline paraíso $^{\dagger}$ & $x$ & $x$ & $x$ & $x$ & $x$ & $x$ & & \\
\hline Morus alba L. & & & & & & & & 027 \\
\hline mora $^{\dagger}$ & & $x$ & & & $x$ & $x$ & & \\
\hline Olea europaea L. & & & & & & & & 028 \\
\hline olivo $^{\dagger}$ & & & & & $x$ & $x$ & & \\
\hline Opuntia ficus-indica & Mill. va & r. ficus & indica & & & & Construction of corral doors & 048 \\
\hline tuna & & & & & $x$ & $x$ & & \\
\hline Parkinsonia acuela & & & & & & & & 029 \\
\hline uña de gato & $x$ & & & & & & & \\
\hline Parkinsonia praeco & iz \& $\mathrm{Pa}$ & v.) $\mathrm{Hal}$ & vkins & & & & Wood for charcoal and brick-ovens & 012 \\
\hline brea & & & $x$ & & $x$ & $x$ & & \\
\hline Pinus sp. & & & & & & & & 030 \\
\hline pino $^{\dagger}$ & $x$ & & $x$ & $x$ & & & & \\
\hline Platanus acerifolia & ) Willd & & & & & & & 031 \\
\hline plátano $^{\dagger}$ & $x$ & & & & & & & \\
\hline Populus alba L. & & & & & & & "Fake wood," "without heart;" not useful & 032 \\
\hline álamo ${ }^{\dagger}$ & $x$ & & & & $x$ & $\mathrm{x}$ & for making coal, so low rated & \\
\hline Porlieria microphyll & ill.) Des & cole, & 'Done & II \& Lo & urteig & & & 033 \\
\hline pan de cata & & & & $x$ & & & & \\
\hline Prosopis alba var. a & Sriseb. & & & & & & Fuelwood, construction, stakes, fences, & 034 \\
\hline algarrobo & $x$ & $\mathrm{x}$ & $x$ & $x$ & $\mathrm{x}$ & $x$ & & \\
\hline
\end{tabular}




\begin{tabular}{|c|c|c|c|c|c|c|c|c|}
\hline \multirow[t]{2}{*}{ Plant names } & \multicolumn{6}{|c|}{$\begin{array}{l}\text { Communities in } \\
\text { phytogeographical areas of chaco }\end{array}$} & \multirow[t]{4}{*}{ Main uses } & \multirow{4}{*}{ 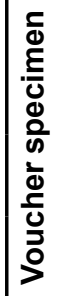 } \\
\hline & \multicolumn{2}{|c|}{ serrano } & \multicolumn{2}{|c|}{ seco } & \multicolumn{2}{|c|}{ árido } & & \\
\hline \multirow[b]{2}{*}{ Vernacular } & en & & & & & & & \\
\hline & 吾定 & 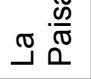 & ๙ & $\frac{\sqrt{0}}{0}: \frac{\circ}{0}$ & $\stackrel{\frac{E}{\pi}}{\mathscr{N}} \stackrel{\frac{E}{\pi}}{\Sigma}$ & 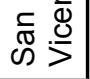 & & \\
\hline \multicolumn{7}{|c|}{ Prosopis kuntzei Harms. } & \multirow{2}{*}{$\begin{array}{l}\text { Fuelwood, although produces lots of } \\
\text { sparks }\end{array}$} & \multirow[t]{2}{*}{035} \\
\hline itín & & & $\mathrm{x}$ & $\mathrm{x}$ & & & & \\
\hline \multicolumn{7}{|c|}{ Prosopis nigra var. nigra Hieron. } & & \multirow[t]{2}{*}{036} \\
\hline algarrobo negro & $\mathrm{x}$ & & & $\mathrm{x}$ & & & & \\
\hline \multicolumn{7}{|c|}{ Prosopis torquata (Lag.) DC. } & \multirow[t]{2}{*}{ Fuelwood } & \multirow[t]{2}{*}{037} \\
\hline tintitaco & $\mathrm{x}$ & & & $\mathrm{x}$ & & & & \\
\hline \multicolumn{7}{|l|}{ Prunus sp. } & & \multirow[t]{2}{*}{038} \\
\hline \begin{tabular}{l|l} 
ciruelo \\
\end{tabular} & & $\mathrm{x}$ & & & & & & \\
\hline \multicolumn{7}{|l|}{ Ruprechtia apetala Wedd. } & & \multirow[t]{2}{*}{039} \\
\hline \begin{tabular}{l|l} 
manzano del cam- \\
po
\end{tabular} & & $x$ & & $\mathrm{x}$ & & & & \\
\hline \multicolumn{7}{|c|}{ Salix humboldtiana var. humboldtiana Willd. } & & \multirow[t]{2}{*}{040} \\
\hline sauce & $\mathrm{x}$ & $\mathrm{x}$ & & & & & & \\
\hline \multicolumn{7}{|c|}{ Schinopsis balansae Engl. } & \multirow{2}{*}{$\begin{array}{l}\text { Excellent wood, not very used because of } \\
\text { its low availability }\end{array}$} & \multirow[t]{2}{*}{041} \\
\hline $\begin{array}{l}\text { quebracho colora- } \\
\text { do }\end{array}$ & $x$ & & $x$ & & & & & \\
\hline \multicolumn{7}{|l|}{ Schinus areira $\mathrm{L}$. } & & \multirow[t]{2}{*}{042} \\
\hline aguaribay & $\mathrm{x}$ & $x$ & $\mathrm{x}$ & & & & & \\
\hline \multicolumn{7}{|c|}{ Schinus fasciculata var. fasciculata (Griseb.) I.M.Johnst. } & \multirow{2}{*}{$\begin{array}{l}\text { "Fake wood," not useful for making coal, } \\
\text { burns with an unpleasant odor so low rat- } \\
\text { ed }\end{array}$} & 043 \\
\hline moradillo & $\mathrm{x}$ & $\mathrm{x}$ & $x$ & $\mathrm{x}$ & & & & \\
\hline Senna aphylla (Cav.) H.؟ & S.Irwin & \& Barn & eby & & & & Fire ignition; used as brooms & 044 \\
\hline pichanilla & & & & & $x$ & & & \\
\hline Stetsonia coryne (Salm- & Dyck) B & ritton $\varepsilon$ & Rose & & & & Construction of corral doors & 045 \\
\hline cardón moro & & & $x$ & & & & & \\
\hline Ulmu ssp. & & & & & & & & 046 \\
\hline olmo & $x$ & & & $x$ & & & & \\
\hline Zanthoxylum coco Gillies & $\mathrm{sex} \mathrm{Ho}$ & ok. f. 8 & Arn. & & & & "Soft wood," not very appreciated & 017 \\
\hline coco & & $x$ & & & & & & \\
\hline Ziziphus mistol Griseb. & & & & & & & & 047 \\
\hline mistol & $\mathrm{x}$ & & $x$ & $\mathrm{x}$ & & & & \\
\hline
\end{tabular}

